\title{
Impact of Statelessness: Are We Ready to Face?
}

\author{
Bilkis Afroza Siddika \\ Assistant Director, Department of Immigration \& Passports, Dhaka, Bangladesh \\ Email: afroza26@yahoo.com
}

How to cite this paper: Siddika, B.A. (2019) Impact of Statelessness: Are We Ready to Face? Open Journal of Social Sciences, 7, 1-11. https://doi.org/10.4236/jss.2019.712001

Received: October 14, 2019

Accepted: November 30, 2019

Published: December 3, 2019

Copyright $\odot 2019$ by author(s) and Scientific Research Publishing Inc. This work is licensed under the Creative Commons Attribution International License (CC BY 4.0).

http://creativecommons.org/licenses/by/4.0/

(c) (i) Open Access

\begin{abstract}
Rise in number of stateless people across the world over the years has manifold implications that have been mostly overlooked. Millions of stateless people around the world, who are least visible but most vulnerable group, pose a threat to social harmony and international security. In a state of growing interdependency among States, impact of statelessness may not be confined within the territory of the State concerned. This paper is an endeavour to find out root causes of statelessness based on scholarly literatures and reports on statelessness and identify probable consequences that may derive from rising number of statelessness considering recent facts of statelessness in some Asian countries. This paper also discusses legal frameworks to address statelessness and response of international community to this issue. Finally, this paper discusses responses required to prevent statelessness and to meet the future challenges of statelessness.
\end{abstract}

\section{Keywords}

Statelessness, Nationality Policy, Forced Displacement, State Security, Human Rights Violation, Socio-Economic Implications

\section{Introduction}

An estimated 10 to 15 million people around the world are stateless [1]. That means they do not belong to any state. No State considered them as their own nationals. Statelessness is a man-made problem, in many cases it takes years to find a solution. Situations of statelessness aggravated in many parts of the world since 1980s except in the Americas. In some recent phenomena, State policies made thousands of people stateless from a State where they were residing for decades or even generation after generation for centuries. The status of statelessness puts life of individuals at stake and vulnerable to forced displacement. They flee because of the persecution but later find it impossible to return back to their home. Their journeys of life become miserable with unlimited uncertainty. 
Stateless people exist all over the world but there is no exact data of stateless people. UNHCR (the Office of the United Nations High Commissioner for Refugees) estimates that there are millions of stateless people globally including children. Large numbers of populations mainly ethnic and minority groups are affected by statelessness in some countries that include Myanmar, Latvia, Estonia, Kuwait, Thailand, Iraq, Dominican Republic, Cambodia, Cote d'Ivoire, Palestine, Zimbabwe, Ivory Coast, India, Syria, Germany, Bhutan, and Lebanon. "Statelessness is a major 'push' factor leading to large-scale irregular migration." [2]. It also poses threat to security of States and regional stability. To a great extent international community's recent interest in statelessness and nationality disputes has been generated due to fear of instability, conflict and displacement of population in the geopolitically sensitive areas.

The United Nations General Assembly adopted the 2030 Agenda for Sustainable Development to be achieved by the year 2030 consists of 17 Sustainable Development Goals (SDGs) and 169 accompanying targets that include ensuring safe migration of people. But there is no target stipulated considering the stateless people. Stateless people cannot even migrate to other countries through proper immigration procedures without having valid national identity. More importantly, ensuring human rights of statelessness people is a challenge for the international community.

\section{Citizenship versus Statelessness}

Citizenship provides individuals a status of membership to a nation-state. Loss and acquisition of citizenship falls under the purview of sovereign State. Under nationality policy, State provides citizenship to a person by place of birth (jus soli), by descent from a one or both parents who are nationals of the concerned State (jus sanguinis), or by naturalization. Based on citizenship, or nationality, classification of peoples and distribution in polities across the globe is determined. The concept of citizenship is associated with three fundamental issues. These are "how the boundaries of membership within a polity and between polities should be defined; how the benefits of and burdens of membership should be allocated; and how the identities of membership should be comprehended and accommodated." [3].

Individuals linked to a sovereign country hold the legal bond of nationality which results in mutual rights and duties. On the basis of this legal bond, citizens enjoy the full political rights including right to vote and are entitled to get protection from the State, particularly protection in abroad. A long tradition of enjoying citizenship can unite the members of a polity under any sort of challenges. Citizenship also fosters a form of identification and social integration. In liberal society, citizenship gives a sense of solidarity that avoids the divisiveness of ethnic, racial, and religious affiliations or membership to minority group. Due to the movement of people across the world, the notion of citizenship is getting more significance in international political arena. "Although citizenship has tra- 
ditionally been conceived as primarily a domestic concern of states, the reality of immigration and emigration, the formation of such supranational bodies as the European Union (EU), the formation of new successor states, the movement of refugee populations, and the codification of international human rights norms has prompted increasing recognition of citizenship as a transnational matter." [3].

On the contrary, statelessness takes away the identity of an individual and so, no membership to any polity and no question of allocation of benefits. They do not have the same rights and opportunities enjoyed by the citizens of a nation-state. Article of 1 of 1954 Convention Relating the Status of Stateless Persons defines a stateless person as an individual who is "not considered as a national by any state under the operation of its law". Some stateless persons are also refugees who have been forced to leave their country of origin. Unlike the nationals, stateless people do not hold any legal bond with any nation-state. They cannot enjoy the rights which are entitled to the citizens or nationals. Stateless people are denied government-issued identification, health care, freedom of movement, and are prevented from getting formal jobs, enrolling in a school, or even get married. "Denial of these rights impacts not only the individuals concerned but also society as a whole, in particular because excluding an entire sector of the population can lead to social tensions and significantly impair economic and social development." [4].

\section{What Causes Statelessness?}

In principle, it is the nation-state that regulates the acquisition and loss of its nationality. There are diverse reasons of statelessness which are consistent worldwide. Cleaning of unwanted people based on religious identity so far has been one of the main causes of statelessness [5]. State policy aimed at suppression of certain religious or ethnic minority group creates statelessness. For instances, the Rohingyas became stateless through the controversial Citizenship rules, 1982 in Myanmar and the Kurds in Syria became stateless in 1962 through a controversial census.

"Conflicts of or gaps within nationality laws can lead to statelessness in the everyday operation of these rules, if not addressed." [5]. Discriminatory state regulations on the basis of gender, ethnicity, or religious identity sometimes cause statelessness. For example, "in 27 countries worldwide, women are not entitled to transmit nationality to their children on equal term as men. This gender discrimination can leave children stateless where their father is stateless, unknown or unable to transmit his nationality." [6]. For instance, Syrian war left about 3 million people displaced and put them at a risk of statelessness as many families were not registered before fleeing abroad. And those 8000 children who lost their fathers or are separated from their fathers are at risk of statelessness as in Syria children acquire nationality only through their fathers [7].

Statelessness sometimes results from deliberate exclusion of particular group of people from nationals' documentation. For example, in Assam, India, about 
1.9 million people have been excluded from Indian citizenship registration, $\mathrm{Na}$ tional Registry of Citizens (NRC). Most of the excluded persons are Muslim who are unable to provide proof of their nationality or ancestry to meet the requirements of civil documentation in India [8].

Some people are born stateless when their parents are stateless. Due to war in Syria, most of the 51,000 Syrian babies who were born in exile may become stateless as their parents are stateless refugees and have not been registered [6]. Some people become stateless due to the emergence of new States, dissolution of an existing state and transfers of territory between existing States. According to UNHCR report, in Côte d'Ivoire, approximately 700,000 Burkinabé descent migrants are stateless who could not acquire Ivorian nationality after the country's independence from France in 1960. Statelessness due to the dissolution of former states also continues to affect many people, including some 600,000 people in Europe alone [9]. In Germany, Poland, and Sweden, stateless people are reported to number close to or more than 10,000 [5].

Situations of displacement can also increase the risks of statelessness because later they find it difficult to proof their nationality. For instance, in 1962, about 120,000 Kurds became stateless as they could not provide the proof of their residence in Syria since 1945 in a one-day census in the al-Hasakeh province [10]. Similarly, displaced Rohingyas repatriation is getting complicated as they lack nationality document. Therefore, statelessness is mainly a man-made problem, often "results of poor, discriminatory or even malignant nationality policy." [5].

\section{Impact of Statelessness}

Statelessness is a major challenge for many States where a large number of people are affected by statelessness. Losing all the rights of citizens, they also lose their habitat, in many cases, are displaced from the country where they were born and brought up. When an individual become statelessness on any ground, usually effect is limited to the individual and his/her family only. But when communities become stateless, this can lead to conflict and cause displacement, spread terrorism or even contribute to war. When statelessness causes forced displacement of communities, their movement to neighbouring country results in regional as well as international tension.

Palestinians constitute the largest community of stateless people in the world living as refugees for four generations since 1948. "Today more than half of the eight million or so Palestinians are considered to be de jure stateless persons." [2] They are not recognized in any other countries. Palestinians were expelled from Kuwait in 1991 and from Libya in 1995 and some are living as refugees in Lebanon and Egypt and Saudi Arabia where they cannot apply for naturalization.

In 2017, denial of citizenship, forced labor, killing, rape, arson and arbitrary confiscation of property compelled the Rohingyas in Myanmar to flee and take shelter in neighbouring country, Bangladesh. According to the UNHCR, the exodus of Rohingyas began on 25 August 2017 when violence broke out in Myan- 
mar's Rakhine State, driving more than 723,000 to seek refuge in Bangladesh [11]. They were displaced without anything, without any national document. Plight of Rohingyas is not a new phenomenon. They have been facing persecution for long time. "Thousands of Rohingya fled to what is now Bangladesh in four main periods: the late 1700s and early 1800s, the 1940s, 1978 and, most recently, in 1991 and 1992." [12]. Since the early 1990s over a million Rohingyas fled Myanmar due to forced labor, rape and religious persecution at the hands of the Burmese army. "With the assistance of UNHCR and non-governmental relief agencies, the Bangladeshi government sheltered the refugees in nineteen camps in the vicinity of Cox's Bazar in southeastern Bangladesh.” [12]. Without having access to formal job opportunities, they are engaging in criminal activities and drug trafficking [13] and causing a continuous tension for the host country. Though the government of Bangladesh attempted to repatriate Rohingyas through negotiation, but any sustainable solution of this issue is yet to figure out.

Statelessness of Rohingyas not only affects the law and order situation and socio-economic conditions of Bangladesh, but also affects the other countries where they are trying to intrude. According the Straitstimes report published on March 1, 2019, thirty-four Rohingya were found on a beach in Malaysia on March 1, 2019 thought to have arrived in the country by sea for almost a year and those shattered people including men, women and children were taken in the custody of the immigration authorities [14], A German based news portal reported on 14 August 2017 that some 16,500 Rohingyas from Myanmar were registered with the United Nations High Commissioner for Refugees (UNHCR) in India [15]. According to that report the Indian government planned to deport thousands of Rohingya Muslims living in the country illegally considering them as a security threat having link with terrorist group.

Stateless Syrian children who lost their fathers during the war cannot access healthcare and education without identity documents. Moreover, in adolescence, the lack of papers proving their age puts them at risk of early marriage, child labor, recruitment by armed forces and being trafficked [7].

Stateless people cannot claim any rights enjoyed by the citizens or nationals of a State, even their lives are threatened without having protection from a State. As stateless people are not considered as citizens, they are not included in the development process of the State. Moreover, arbitrary denial of citizenship of a group of people in some cases associated with forced displacement from the originating country to another causes regional or international tension and instability. Meeting the immediate needs of refugees is one thing, but if governments fail to recognise the long-term impacts of statelessness, a new generation could grow up in limbo [16]. In many cases, the miseries of stateless people are subsided because stateless people are often remained unseen and unheard due to unwillingness of the concerned government to highlight the issue. But this largely invisible issue of statelessness could have long-term consequences for the states.

Statelessness has socio-economic implications also. When large number of 
people are deprived of any job opportunities or denied operating a business for earning their living, they cannot contribute to the economy rather become a challenge for the society. Stateless persons are often excluded from the development process. Due to extreme poverty, in some cases, stateless parents become bound to sell their children. Without any citizenship documents, stateless persons often don't have the basic rights that enjoyed by the citizens. Moreover, they don't have the right to vote, obtain a passport, travel, entering another country with valid visa, participate in public affairs, own property, or even access to health care facilities. They become a social inertia with unlimited uncertainty. Stateless people are also deprived of social welfare, housing, freedom of movement, and freedom from arbitrary detention. Feeling of deprivation of any kind and feeling of being alienated and excluded from the society can create resentment among the members of the excluded communities. Statelessness due to discriminatory action by state, may lead the deprived groups engage in subversive activities.

Forcibly displaced stateless people find crossing international borders difficult or impossible as there is no globally agreed legal or orderly arrangement for safe migration of a stateless person. For instance, many stateless Syrian Kurds tried to enter European countries by illegal ways and still this trend continues. They often take risk of their life, face administrative detention, and deportation. To prevent illegal infiltration, tightened policies are applied during immigration. However, without any place to which to be deported, the detention time for the stateless prolongs for indefinite time. In case of Muslims in Assam, India, the undocumented Muslims, according to news reports are likely to face deportation [8].

Statelessness, as the absence of the right to a nationality, is complete violation of human rights. Deliberate exclusion of any group of people on grounds of their race, ethnicity, language, or religion is an intrinsic human rights problem. Many stateless people start life without any national identification document and without protection from the state. Thus, statelessness means a lifetime hardship with uncertainty. No opportunity to work to earn for living makes their lives more miserable. Stateless people also lack access to any sort of social security, pension entitlements, or any other support from the state. Without having any recognized national identity, stateless persons are more susceptible to trafficking, institutionalized discrimination, forced displacement, arbitrary detention, violence, and a range of human rights violations. For instance, Rohingyas in Myanmar were deliberately deprived of education, security of life, health services and marginalized for long time from all sort of social welfare. Stateless people all over the world go through a range of human rights abuses. Stateless persons are sometimes called "legal ghosts", a vulnerable group prone to rights abuses, detention and exploitation.

State's revision of nationality policy targeting some people to be alienated and snatching their right to nationality and forcibly displace or deport them generate some questions like; where the stateless person will be deported? Are all the 
neighbouring countries ready to welcome those people who are made stateless arbitrarily? What may happen if all states start cancelling nationality to those who were once recognized as citizens or granted citizenship through naturalization process? In these circumstances, international community need to rethink about individual's right to nationality, nationality disputes and find out a sustainable solution that would prevent generating any new case of statelessness.

\section{Legal Framework to Address Statelessness}

With an endeavour to address statelessness, international community has concluded some international agreements. Adoption of 1948 Universal Declaration on Human Rights was the first to recognise right to nationality as fundamental right. Article 15 of the 1948 Universal Declaration of Human Rights provides:

"1) Everyone has the right to a nationality;

2) No one shall be arbitrarily deprived of his nationality or denied the right to change his nationality."

Since the adoption of 1948 Universal Declaration of Human Rights, right to a nationality has been reiterated in every subsequent universal and regional human rights treaties. But still there are thousands of people around the world who lack the security and protection that a citizen can have.

The 1954 Convention relating to the Status of Stateless Persons has been the foundation of the international protection regime for stateless persons providing the definition of a stateless person. The 1954 Convention was designed to regulate the treatment of de jure stateless people. It establishes minimum standards of treatment for stateless people with respect to the right to education, employment and housing and guarantees stateless person various rights including right to identity, travel documents and administrative assistance. The 1961 Convention on the Reduction of Statelessness was intended to prevent the new cases of statelessness by addressing the problem occurring at birth or later in life. It also sets out important safeguards to prevent statelessness due to loss or renunciation of nationality or state succession [17].

International instruments such as the International Covenant on Civil and Political Rights (ICCPR), the International Convention on the Elimination of All Forms of Racial Discrimination (CERD), the Convention on the Elimination of Discrimination against Women (CEDAW), the Convention on the Rights of the Child (CRC), the International Convention on the Protection of the Rights of All Migrant Workers and Members of Their Families, and the Convention on the Rights of Persons with Disabilities (CRPS) also contain provisions relating to the right to nationality and contribute to the protection of stateless persons and the prevention of statelessness.

Meanwhile, some obligatory frameworks have been stipulated by State parties at regional level that complement the international statelessness conventions. For instances, 1969 American Convention on Human Rights, Commonwealth of Independent States Convention on Human Rights, Fundamental Freedoms of 
1995, the ASEAN Human Rights Declaration of 18 November 2012, and the European Convention on Nationality of 1997 recognise the right to nationality of every person.

But it is the State that sets the rules for acquisition, change and loss of nationality as part of its sovereign power. At the same time, regarding nationality, the discretion of States is limited by the obligations under which international treaties they are parties. Ironically, most of the countries where large number of people have been made stateless, are not parties to the Conventions relating to the protection of stateless people.

\section{Response of International Community to Statelessness}

The Office of the United Nations High Commissioner for Refugees (UNHCR) was given mandate by the UN General Assembly to identify and protect stateless people and to prevent and reduce statelessness in 1995. Prior to that accession to two statelessness convention of 1954 and 1961 was very low and statelessness was a low priority issue for the international community. During the Cold war period, the issue of statelessness failed to attract significant amount of attention of international communities. By the end of the 1980s, due to rise of consciousness, the increased number of communal conflicts, dissolution of several federal polities like USSR, Yugoslavia and Czechoslovakia, curbing immigration in many industrialized countries and the fear of mass exodus of people, the issue of statelessness was incorporated in international humanitarian and security agenda.

So far, UNHCR has worked actively to fulfil its mandate by working with governments, other UN agencies and civil society to address the statelessness problem. To a greater extent UNHCR continuous campaign to address statelessness contributed to rise in parties to the 1954 Convention to 80 and parties to the 1961 Convention to 55. UNHCR is working as coordinating partner in realizing reformation in nationality law or policy to reduce statelessness through automatically acquisition of nationality. For example, in Sri Lanka, UNHCR collaboration with the Government of Sri Lanka and the Ceylon Workers Congress helped almost 200,000 statelessness Hill Tamils to acquire Sri Lankan nationality through law reform. Similarly, in resolving the case of statelessness of 300,000 Urdu-speaking "Bihari” in Bangladesh, UNHCR played an important liaison role between national campaigners, the international community and the Government of Bangladesh. Biharis became nationals of Bangladesh after Government policy was changed to accommodate a High Court ruling that recognized this group as nationals in 2008 [5].

Recently the UNHCR launched the \#IBelong global campaign to end statelessness by 2024, with a view to ensure that every person has access to a citizenship within a decade. The campaign commenced with an initial two-year focus on children and youth. This Global Action Plan to End Statelessness: 2014-2024 establishes a guiding framework comprising 10 Actions to be undertaken by States, with the support of UNHCR and other stakeholders. The Global Action 
Plan is intended to resolve existing major situations of statelessness and prevent emerging new cases of statelessness. UNHCR and UNICEF recently also launched a global coalition on every child's right to a nationality with various initiatives to address childhood statelessness.

In 2015, UN adopted a sustainable development agenda, namely Sustainable Development Goals (SDGs) to be fulfilled by 2030. Though there is nothing explicit regarding stateless persons development, the core focus of the SDGs "no one must be left behind" clearly applies to everyone. Among its 17 goals, goal 16 seeks to promote peaceful and inclusive societies for sustainable development, provide access to justice for all and build effective, accountable and inclusive institutions at all levels. Along with this goal, if other targets like elimination of gender discrimination (Target 5.1 of SDG 5), and providing legal identity for all, including birth registration (Target 16.9 of SDG 16) can be implemented effectively, then it may contribute to reduce statelessness.

Other UN agencies, NGOs and academics also have a role to play in the identification and addressing the problem of statelessness. At regional level, in Europe, America and Africa measures have been taken to prevent statelessness and protection of the basic rights of stateless persons. For instance, in October 1992, an agreement signed among CIS states (Commonwealth of Independent States) to provide the necessary documents to formerly deported people recognizing their social, economic and political rights. European convention on Nationality is also an attempt to establish a regional framework addressing the issues of citizenship and statelessness.

In last few years some states have taken positive initiatives to solve problem of statelessness. In 1994-95, Lebanon granted citizenship to more than 10,000 stateless persons from Middle Eastern minority group. In 2007, Brazil's reform in constitution helped transforming 200,000 stateless people into citizens. In these exemplary successes of reducing statelessness of thousands of people, it is evident that political will of a State can solve this apparently intractable problem because the task of granting or denying nationality is under jurisdiction of sovereign State.

\section{Conclusions}

So far, statelessness is seen as a low priority policy concern, but this invisibility may escalate into regional or international instability. The states, where a large number of people are made stateless through discriminatory nationality policy, are not parties to the international conventions relating to the statelessness. Non-acceptance of these conventions is a major challenge for solving the problem of statelessness and also regarding humanitarian assistance for the stateless people. Most importantly, statelessness is a major impediment in realizing goals of sustainable development when certain groups of people are excluded from opportunities, services, and the chance for a better life. If the issue of statelessness is not addressed properly, it is impossible for the work towards the Sustainable Development Agenda, a dream of the all inclusive world. 
Statelessness can be eradicated through promoting birth registration, promoting accessions to the Conventions on statelessness, providing training and technical assistance to the governments, raising issues of statelessness within multilateral forum, promoting various forms of Parliamentary diplomacy, and raising awareness about statelessness. In addition, under International law, there should be some regulations against States which arbitrarily deny citizenship of a person or a group of people based on their race, religion, language or colour. All efforts will be effective only if there is the will of the State concerned. If all the states formulate anti-racist and non-discriminatory nationality policy and effectively practice such policy, idyllically, there will never develop any situation that will cause emerging new cases of statelessness. UN can play a vital role in realizing this ideal objective. Moreover, every State needs to realize that in a state of growing interconnectedness among people and interdependency among the States, effects of statelessness are also not just confined to within the territory of the country or region. To minimize future risks of statelessness, to resolve nationality disputes effectively, and to meet the humanitarian needs of the existing stateless people, it is necessary to urgently formulate legally binding frameworks for states.

\section{Conflicts of Interest}

The author declares no conflicts of interest regarding the publication of this paper.

\section{References}

[1] The Brookings Institution Report. https://www.brookings.edu/blog/future-development/2015/05/15/the-state-of-statel essness-in-the-middle-east/

[2] Abbas Shiblak (2006) Forced Migration Review, FMR26. Stateless Palestinians. https://www.fmreview.org/sites/fmr/files/FMRdownloads/en/palestine/shiblak.pdf

[3] Aleinikoff, T.A. and Klusmeyer, D.B. (2001) Citizenship Today: Global Perspectives and Practices. Brookings Institution Press, Washington.

[4] UNHCR (2010) UNHCR Action to Address Statelessness; A Strategy Note.

[5] Policy Department, Directorate-General for External Policies (2014) Addressing the Human Rights Impact of Statelessness in the EU's External Action.

[6] UNHCR (2014) Background Note on Gender Equality, Nationality Laws and Statelessness. http://www.refworld.org/docid/532075964.html

[7] https://www.reuters.com/article/us-foundation-syria-crisis-stateless/war-may-make -hundreds-of-thousands-of-young-syrians-stateless-idUSKBN0HC1W420140917

[8] Regan, H. and Suri, M. (2019) 1.9 Million Excluded from Indian Citizenship List in Assam State. CNN Report.

https://edition.cnn.com/2019/08/30/asia/assam-national-register-india-intl-hnk/ind ex.html

[9] https://www.unhcr.org/statelessness-around-the-world.html

[10] Danish National ID Centre (2019) Stateless Kurds in Syria: Maktoumin and Ajanib. 
https://www.nidc.dk/-/media/nidc/Dokumenter/Notatbibliotek/16012019-Syria-Statel ess-Kurds-in-Syria---Maktoumin-and-Ajanib.pdf?la=da\&hash=77263DA0719B3E9 E17E6E2F493F14CF892D148AC

[11] https://www.unhcr.org/ph/campaigns/rohingya-emergency

[12] HRW (2000) Human Rights Watch Report. https://www.hrw.org/reports/2000/burma/burm005-01.htm

[13] Aljazeera (2019) Rohingya Man Arrested in Bangladesh after \$5m Drug Haul. http://www.aljazeera.com/news/2019/10/rohingya-man-arrested-bangladesh-5m-dr ug-haul-191028153848914.html

[14] Straintstimes (2019) Dozens of Rohingya Found on Malaysian Beach after Perilous Sea Journey.

https://www.straitstimes.com/asia/se-asia/dozens-of-rohingya-found-on-malaysianbeach-after-perilous-sea-journey

[15] DW (2017) Deportation looms large over Rohingyas in India.

https://www.dw.com/en/deportation-looms-large-over-rohingyas-in-india/a-40087 915

[16] The Guardian report, "Stateless in Europe: 'We are no people with no nation"” published on March 16, 2019, available at:

https://www.theguardian.com/world/2015/dec/27/stateless-in-europe-refugee-crisis -we-are-no-people-with-no-nation

[17] UNHCR (2014) What Is Statelessness?

https://www.unhcr.org/ibelong/wp-content/uploads/UNHCR-Statelessness-2pagerENG.pdf 